\title{
Trust, Risk and Public History: A View From the United States
}

\author{
JAMES B. GARDNER
}

\begin{abstract}
s part of our work as public historians, more and more of us are Aexperimenting with web 2.0 - Flickr, Facebook, YouTube, Twitter, blogs, Wikis, and the like - and we're finding that engagement with that online world means grappling with very different expectations on the part of the public and new challenges to how we do our work. ${ }^{1}$ In the public history and museum communities in the United States today there is particular concern about the concept of 'radical trust'. Focusing on fostering public loyalty through open communication and expression, the concept first cropped up within the for-profit marketing and advertising world and is now a keystone of social media. ${ }^{2}$ In the public history or museum field, radical trust was used initially for much the same purpose - to foster word-of-mouth engagement in our work. But more recently it has been proposed as the next step in public
\end{abstract}


engagement: looking to the public for content and direction - and that's a radical step for public historians to take. ${ }^{3}$ Essentially, we are challenged to demonstrate our 'radical trust' of the public by giving up control and letting them develop content for our websites and exhibitions and provide direction for our work. In other words, radical trust means letting the public (via online communities) determine the future of public history.

But what is so 'radical' about radical trust? If we take this concept seriously, as more than just pop jargon, we must demonstrate complete trust in the public and in a new self-regulated world of usergenerated content that we as public historians do not direct or control. There is no half-way in radical trust. If we mediate or if we filter out unedited, uncensored opinion, then we are breaching that trust. Colin Douma, one of the first in the marketing world to articulate the concept, warns that the public 'will disconnect with a brand that silences them, and will align with brands that give them a voice. ${ }^{4}$ In other words, the issue is not really including usergenerated content but giving up authority.

For public historians, sharing authority and including usergenerated content in exhibits, programs, and other projects is hardly radical. We've been doing that for decades and have developed a considerable professional literature, rooted in the pioneering work of Michael Frisch. ${ }^{5}$ And we can all point to models of good practice at museums like the Smithsonian's National Museum of American History (NMAH). For example, NMAH's 2002 exhibit 'September 11: Bearing Witness to History' had a section called simply 'Tell Us Your Stories' that was essential to the exhibit's successful navigation of that sensitive subject. With review, what visitors shared in the exhibit and online then became part of a September 11 digital archive that remains accessible electronically today. ${ }^{6}$ That was user-generated content long before any of us were dealing with web 2.0 and radical trust.

But while most of us are happy to share authority with the public, radical trust essentially asks us to give up authority. In embracing radical trust, we seem to be taking historian Carl Becker's wellknown phrase 'everyman his own historian' and updating it to 'every person his or her own curator. ${ }^{7}$ And what I've been reading about 'curating' in a web 2.0 world strikes me as very problematic - there seems to be an assumption in online communities that curating or 
doing history is mainly about selecting and organizing, about little more than personal point of view or preference. ${ }^{8}$ An article published in Advertiser Talk in April 2010 identified a 'show and tell' culture as one of the trends for the next decade: 'In this highly democratized techno-enabled age, people behave as though everyone is entitled to their uncensored, unedited opinion. And those opinions need not be valid or supported by fact, critical thinking or depth of insight. ${ }^{9}$

As public historians we know that curating is about much more it is about making meaning of the past. Curating or doing history is creative and scholarly work, requiring critical thinking, not just sharing, but the majority of what you encounter on YouTube and the like is not really creative or original. Based on data from Forrester Research, one commentator argues that 'a minority of social media users are creators - people who write blog posts, upload photos onto Flickr, or share homemade videos on YouTube ... Less than $1 \%$ of the users of most social Web platform [sic] create original content. ${ }^{10} \mathrm{It}^{\prime} \mathrm{s}$ largely our own fault as public historians if the difference between what is on the web, creative or not, and what we do is not understood. We are often our own worst enemy, failing to share what we do. If we want the public to value what we do, we need to 'share the process of history - how we use evidence, what we don't know, how we form historical conclusions, and how our understanding of the past changes. ${ }^{11}$ That means acknowledging that exhibits (real and virtual) are developed and shaped by individual perspectives and are not the products of some objective institutional authority. We need to help visitors in our museums and online become engaged in history not as a set of facts that they can simply rearrange and share but as a way of understanding and making meaning.

The larger problem is the blurring of the line between knowledge and opinion. Knowledge is at the heart of our brands as historical organizations. Indeed, for institutions like the Smithsonian, people assume we speak with authority even when we don't. We cannot simply walk away from that brand or ignore that expectation. In the same way that we struggle against veneration of 'Great Men' and other elites, we need to resist the current impulse to welcome (and thereby validate) any and all opinions. While I believe strongly that we should share authority with the public (and that memory is critical to what we do as public historians), I do not support abdicating our responsibilities and privileging the public's voice or simply doing what the public votes for, no matter what that might 
be. ${ }^{12}$ As former NMAH curator Steve Lubar warned in an article in The Public Historian some years ago, 'Sharing too much authority ... means simply telling the audience what they already know, or what they want to know, reinforcing memory, not adding new dimensions of knowledge, new ways of approaching problems, new understanding. ${ }^{13}$ As public historians, we cannot just ignore those larger responsibilities.

While some cultural institutions may not feel there is much to lose in embracing radical trust, I know from firsthand experience that the subjects we explore as public historians sometimes attract individuals with problematic if not offensive opinions. For example, the Museum of American History has had to deal with individuals who deny that Japanese Americans were wrongly interned during World War II. We cannot allow such individuals to use us for their own purposes - or our reputations will end up suffering collateral damage. A Washington Post humorist recently described public comments in response to newspaper columns as 'spit-flecked rants that are appended to a product that at least tries for a measure of objectivity and dignity. It's as though when you order sirloin steak, it comes with a side of maggots. ${ }^{\prime 4}$ That's obviously an exaggeration, but the danger is real.

To anyone who argues that there is no evidence that the public will take advantage of radical trust, I can only say that that time will come - and then the damage will be done. As another Washington Post columnist put it regarding the back and forth in the summer of 2010 about whether to allow a mosque to be built two blocks away from the World Trade Center site and about whether Barack Obama is a Christian or a Muslim, 'The nastiness index keeps rising, and all of us are getting sullied in the process. ${ }^{15}$ Indeed nastiness has become something of a game: the pranks initiated by the 4 chan message board have sometimes been fun but other times racist and insensitive. ${ }^{16}$ We in the history field must recognize that the ideas and issues we explore often have political baggage and can be polarizing. They can attract inappropriate and even hateful comments, and we cannot appear to legitimize such views by allowing their posting on our blogs, Facebook pages, and other media. Stepping back and yielding to open, non-controlled, self-governing public engagement may be a popular way to go these days, but I think the public deserves more than that from us as public historians. 
Our challenge is to negotiate a role that both builds on who we are and what our strengths are and also engages and challenges the public in new ways, whether in the virtual or the real world. Rather than assuming the future is about our being impacted by the web 2.0 world, museums and historical organizations need to figure out how we can have impact on that world. We need to figure out how to be more than suppliers of raw material for public use.

Unfortunately, this all comes at a time when I think we as public historians and museums are becoming a bit timid. Thus far, I've argued against taking the risks that I see with radical trust, but now I'm going to argue for taking risks in exhibitions and programs. While that may sound contradictory or inconsistent, I believe risk on the floor of the museum is calculated or manageable risk, one that we have taken in the past and should continue to take in the future. In a curious way, we're ready today to take risk online, in a world we have little control or even influence over, but we recoil from taking risks in our museums, on our own turf. Indeed, in terms of the latter, we've become risk averse - afraid to make mistakes, whether for political reasons or financial. We're producing plenty of OK exhibits, but not many great ones.

Museums have not always been risk averse. The Museum of American History, for example, was at one point known for its edgier exhibitions - including The Disability Rights Movement (2000-2001), Between a Rock and a Hard Place: A History of American Sweatshops, 1820-Present (1998), Science in American Life (opened 1994), Claiming a Public Place: Gay, Lesbian, and Bisexual Pride, 1969-1994 (1994), and Men and Women: A History of Costume, Gender, and Power (1989). Those exhibits explored tricky sociopolitical issues, and the museum knew going in of the potential political consequences. But the sense was that such risk went with the territory - if we are not challenging the public, then we are not doing our job. Indeed the mission statement of the Museum of American History specifically directs us to focus on presenting 'challenging ideas' about the past. ${ }^{17}$

We should not be afraid to try something different or to experiment. In reinterpreting technology collections within the context of business, social, and cultural history in America on the Move (opened 2003) and On the Water: Stories of Maritime America (opened 2009), the museum has taken important steps in that direction, but the reality is that NMAH is otherwise shying away from truly innovative approaches and the historically controversial or 
ambiguous. ${ }^{18}$ Indeed it is better known for its celebratory exhibit of 'national treasures' of popular culture, its First Ladies at the Smithsonian exhibit (opened 2008) that steps away from the more ambitious goals of the earlier First Ladies: Political Role and Public Image, and a military history exhibit straight-jacketed by the title The Price of Freedom (opened 2004). ${ }^{19}$ The last tries to present a nuanced story (although in a non-challenging way), but that goal is severely hampered by a title that frames the exhibit as an uncritical endorsement of the myopic idea that love of freedom is what always motivates Americans. ${ }^{20}$ The museum should be taking more risks, not backing away. One curator has proposed collecting and exhibiting language, a controversial issue in the context of the immigration debate in the United States. While I'm not sure how the museum would go about doing that, I do believe we should give it a try. Unfortunately, it's not on the fundraising priority list. Every now and then, entrepreneurial curators still manage to find the resources to take on challenging topics. For example, NMAH's traveling exhibition Bittersweet Harvest: The Bracero Program, 1942-1964 (opened 2010) focuses on guest workers, a touchy topic in the context of the debates over race, immigration, and identity in the United States. ${ }^{21}$ Indeed, race and ethnicity seems to be the one area in which American museums are willing to push the envelope. Consider, for example, two challenging but widely acclaimed exhibitions: Without Sanctuary: Lynching Photography in America, a traveling exhibition developed by the National Center for Civil and Human Rights (opened 2000); and Slavery in New York, an exhibit at the New-York Historical Society (2000-2006). More recently, the American Anthropological Association and the Science Museum of Minnesota have developed RACE: Are we so different? (opened 2007), a powerful traveling exhibition that uses biological, cultural, and historical perspectives to challenge how Americans today think about race. The success of such exhibits does not, however, mean that race has become an easy subject. As important as those and other exhibits have been in tackling difficult issues, historian Lonnie Bunch remains concerned that museums more broadly are failing to examine 'the complexities, interaction and difficulties of race in America. In essence, much of what institutions create today is better suited to the world of 40 years ago. ${ }^{22}$ 
Even more problematic than race for American museums is sexuality. A daring effort to explore that taboo is an exhibition at the Smithsonian's National Portrait Gallery entitled Hide/Seek: Difference and Desire in American Portraiture (2010-11), a path-breaking look at evolving attitudes toward sexuality, desire, and romantic attachment. ${ }^{23}$ While the National Portrait Gallery is arguably a museum of history or biography (using portraiture to explore identity), one can't help but wonder if this exhibit is viable because it is perceived of as 'art' rather than 'history.' Of course, anyone who remembers the culture wars of the 1990s knows that art exhibits, from 'The West as America' to the works of Robert Mapplethorpe, have been as problematic as history. Whether 'art' or 'history,' Hide/Seek remains an exception - the first major museum exhibition with this focus and a too rare example of risk-taking, all the more unexpected and daring at a Smithsonian museum during a time of considerable political turmoil.

Apart from such exceptions, the unfortunate reality is that most American museums are choosing to keep their heads down, becoming not the 'safe place for unsafe ideas' that Elaine Gurian proposed, but little more than safe places for safe ideas. ${ }^{24}$ Why? A facile answer would be to argue that this retreat is part of the fallout from the culture wars of the 1990s. While there has certainly been an unfortunate tendency toward self censorship in post 'Enola Gay' America, that alone does not explain our reluctance to take risks. ${ }^{25}$ I'm more concerned about the impact of changes within the museum culture, changes in how we do business that are shaping and limiting our intellectual agendas. Consider, for example, money. As museums raise more and more money from outside sources and make longer and longer commitments to donors in return, we too often settle for OK in our exhibits. We can't take risks when we're spending millions of dollars on an exhibit that has to be up for decades. Too much is invested and too much is at stake to risk failing. At the same time museums have to deal with donors and other stakeholders who have ideological agendas. We can downplay those points of view, but it's problematic to tackle them head on. And of course trying to compete in an experience-driven, tourist-driven economy throws off balance our role in contemporary life.

Museums are becoming places that challenge less and entertain more. With every new exhibit, we feel that we have to have more technological 'bells and whistles' to 'wow' our visitors - and that's 
where a lot of the money's going. I'm not arguing for some Luddite approach to exhibitions but rather for thinking through how we can use technology and media not simply as entertainment or attention grabbers but as vehicles for engaging the public in the past. The Center for the Future of Museums of the American Association of Museums brought in a speaker a few years ago to talk about applying the principles of online gaming to museum experiences. She didn't propose that museums create games based on exhibits or collections so much as that we think about how the structure of gaming can provide a new approach to what we do, new ways to engage the public. ${ }^{26}$ In other words, she proposed that we can learn from gaming about how to structure knowledge and learning for new audiences, and that's very different from simply adding in new 'bells and whistles' for entertainment.

So what is the role of the public historian? On one side we're told to give up authority to the public, and on the other we're expected to take the safe route, prisoners of politics, the economics of exhibitions, and infotainment. That's a pretty bleak situation and likely to get worse. In The Shallows: What the Internet is Doing to Our Brains, Nicholas Carr warns that our immersion in all things online may have profound consequences for not only our intellectual lives but also our culture: 'Even as the Internet grants us easy access to vast amounts of information, it is turning us into shallower thinkers, literally changing the structure of our brain.' He warns of a world in which our brains are 'rewired,' where surfing the Web is more valued than thinking. ${ }^{27}$ Public historians can either yield to that sad scenario or fight it. We need to be thought leaders, not followers - not wait to see what the future holds for us but rather try to shape that future. At the end of the day, we need to continue to explore history, to do our best to engage the public, to do public history - and to take risks.

\section{Endnotes}

\footnotetext{
${ }^{1}$ Coined around 2004, the term 'web 2.0' is used to describe a virtual world that is user-centered and is best illustrated by the collaborative dynamic of Wikis, blogs, Facebook, and other social media - in contrast to passive viewing of content that is generated by website creators. For a discussion by Tim O'Reilly, arguably the originator of the concept, see 'What Is Web 2.0: Design Patterns and Business
} 
Models for the Next Generation of Software' (Online). Available: http://oreilly.com/web2/archive/what-is-web-20.html (Accessed 5 October 2010).

2 See Collin Douma, 'Radical Trust,' Marketing Magazine, 28 August 2006 (Online). Available: http://www.radicaltrust.ca/wpcontent/uploads/2007/10/radical trust.pdf (Accessed 5 October 2010).

${ }^{3}$ For a discussion of the concept within the public history community in the United States, see Tim Grove, 'History Bytes: Grappling with the Concept of Radical Trust,' History News, Spring 2010, pp 5-6 (Online). Available: http://aaslhcommunity.org/historynews/files/2010/07/spring2010-history-bytes.pdf (Accessed 5 October 2010). See also follow up online discussion, 'Grappling with Radical Trust' (Online). Available: http://aaslhcommunity.org/historynews/radical-trust/ (Accessed 5 October 2010).

${ }^{4}$ Collin Douma, op cit.

5 The term 'shared authority' comes from Michael Frisch, A Shared Authority: Essays on the Craft and Meaning of Oral and Public History, State University of New York Press, Albany, 1990.

${ }^{6}$ For a virtual version of the exhibit, see 'September 11: Bearing Witness to History' (Online). Available:

http://americanhistory.si.edu/exhibitions/exhibition.cfm?key $=38 \&$ exkey $=90$ (Accessed 5 October 2010). For the digital archive, see 'September 11: Tell Your Story’ (Online). Available: http://911digitalarchive.org/smithsonian/ (Accessed 5 October 2010).

${ }^{7}$ Carl Becker, 'Everyman His Own Historian,' American Historical Review, vol 37, no 2, 1931, pp221-36 (Online). Available:

http://www.historians.org/info/aha history/clbecker.htm (Accessed 5 October 2010).

${ }^{8}$ For a discussion of the changing meaning of 'curating,' see N. Elizabeth Schlatter, 'A New Spin: Are DJs, Rappers and Bloggers "Curators”?' Museum, January/February 2010 (Online). Available: http://aamus.org/pubs/mn/newspin.cfm (Accessed 5 October 2010).

9 '2010 and Beyond: Emerging and Evolving Trends,' Advertiser Talk (Online). Available: http://www.advertisertalk.com/2010-and-beyond-emerging-andevolving-trends-12282.zhtml (Accessed 5 October 2010).

${ }^{10}$ For a discussion of creativity on the web, see Nina Simon, 'Self-Expression is Overrated: Better Constraints Make Better Participatory Experiences,' Museum 2.0 Blog, 16 March 2009 (Online). Available: http://museumtwo.blogspot.com/2009/03/self-expression-is-over-rated-better.html (Accessed 5 October 2010).

11 James B. Gardner, 'Contested Terrain: History, Museums, and the Public,' The Public Historian, vol 26, no 4, 2004, p19.

${ }^{12}$ See, for example, David Glassberg, 'Public History and the Study of Memory', The Public Historian, vol 18, no 2, 1996, pp7-23.

${ }^{13}$ Steven Lubar, 'In the Footsteps of Perry: The Smithsonian Goes to Japan', The Public Historian, vol 17, no 3, 1995, pp46.

${ }^{14}$ Gene Weingarten, 'A Digital Salute to Online Journalism', The Washington Post, July 18, 2010, pW32.

${ }^{15}$ Howard Kurtz, 'In Journalism's Crossfire Culture, Everyone Gets Wounded', The Washington Post, August 2, 2010, pC1. 
${ }^{16}$ See Ariana Eunjung Cha, ‘4chan Users Seize Internet's Power for Mass Disruptions', The Washington Post, 10 August 2010, pA01 (Online). Available: http://www.washingtonpost.com/wpdyn/content/article/2010/08/09/AR2010080906102.html?sid=ST2010080906103 (Accessed 5 October 2010).

${ }^{17}$ For the complete NMAH mission statement see 'Mission \& History' (Online). Available: http://americanhistory.si.edu/about/mission.cfm (Accessed 5 October 2010).

${ }^{18}$ Virtual versions of America on the Move and On the Water are available on the NMAH website. See 'America on the Move' (Online). Available: http://americanhistory.si.edu/onthemove/ (Accessed 23 November 2010) and 'On the Water' (Online). Available: http://americanhistory.si.edu/onthewater/ (Accessed 15 October 2010).

${ }^{19}$ A virtual version of The Price of Freedom is available on the NMAH website. See 'The Price of Freedom: Americans at War' (Online). Available: http://americanhistory.si.edu/militaryhistory/ (Accessed 15 October 2010).

${ }^{20}$ For a scholarly review of the exhibit, see Carole Emberton, 'JOURNAL ARTICLE TITLE', The Journal of American History, vol 92, no 1, 2005 (Online). Available: http://www.historycooperative.org/journals/jah/92.1/exr_2.html (Accessed 5 October 2010).

${ }^{21}$ For a virtual version of the exhibit, see 'Bittersweet Harvest: The Bracero Program 1942-1964' (Online). Available: http://americanhistory.si.edu/exhibitions/exhibition.cfm?key $=38 \&$ exkey $=1357$ (Accessed 5 October 2010).

${ }^{22}$ Lonnie G. Bunch III, “People Need to Remember": American Museums Still Struggle with the Legacy of Race', Museum, vol 89, November/December 2010, p47.

${ }^{23}$ The catalogue for the exhibit is David C. Ward and Jonathan Katz, Hide/Seek: Difference and Desire in American Portraiture, Smithsonian Books, Washington, DC, 2010.

${ }^{24}$ Elaine Heumann Gurian, 'Offering Safer Public Spaces,' Journal of Museum Education, vol 21, no 1, 1995, pp14-16.

${ }^{25}$ For a discussion of the impact of the culture wars on museums, see Lonnie G. Bunch III, Call the Lost Dream Back: Essays on History, Race and Museums, The AAM Press, Washington, DC, 2010, pp129-39.

${ }^{26}$ For her 2 December 2008 lecture, see Jane McGonigal, 'Gaming the Future of Museums' (Online). Available: http://www.futureofmuseums.org/events/lecture/mogonigal.cfm (Accessed 5 October 2010).

${ }^{27}$ Nicholas G. Carr, The Shallows: What the Internet is Doing to Our Brains, W.W. Norton \& Co., New York, 2010. For an excerpt from the book, see Nicholas G. Carr, 'The Web Shatters Focus, Rewires Brains,' Wired Magazine, 20 June 2010 (Online). Available: http://www.wired.com/magazine/2010/05/ff_nicholas_carr/all/1 (Accessed 6 October 2010). 